\title{
Impact of Financial Inclusion towards Poverty in Indonesia
}

\author{
Anas Iswanto Anwar ${ }^{1}$ \\ Amiruddin Amrullah² \\ ${ }^{1,2}$ Hasanuddin University, Makassar - Indonesia \\ Email: aianwar@fe.unhas.ac.id
}

\begin{abstract}
.
Financial inclusion becomes a new phenomenon in the global financial system, including in Indonesia. Financial inclusion is often associated with poverty. Developing countries tried to pursue economic growth as one of the main indicators of their development. However, in reality, many developing countries have high economic growth but produce high poverty rates as well. This study tries to look at the relationship between financial inclusion and poverty, as well as to measure inequality as measured by Gini coefficients. This research found that financial inclusion can affect overall economic growth thereby reducing poverty, but can increase inequality.
\end{abstract}

Keywords: Financial Inclusion, Income Inequality, Poverty Reduction.

\section{A. INTRODUCTION}

Along with the economic development in Indonesia, which is related to poverty alleviation, and the income gap and the formal and informal knowledge about institutional institutions that help the underprivileged community in improving the economy of the underprivileged are the concern of many countries and organizations.

Financial inclusion becomes a new phenomenon in the global financial system, including in Indonesia. Financial inclusion is often associated with poverty. Developing countries tried to pursue economic growth as one of the main indicators of their development. However, in reality, many developing countries have high economic growth but produce high poverty rates as well.

Financial inclusion is a broad concept. As defined by Sarma (2008), financial inclusion is the process that ensures the ease of access, availability, and usage of a formal financial system for all members of an economy. However, it is also important to distinguish between voluntary versus involuntary exclusion. The World Bank (2014) defines voluntary exclusion as a condition 
where the segment of the population or firms choose not to use financial services either because they have no need for them or due to cultural or religious reasons. In contrast, involuntary exclusion arises from insufficient income and high-risk profile or due to discrimination and market failures and imperfections. Policy and research initiatives must then focus on involuntary exclusion as it can be addressed by appropriate economic programs and policies which can be designed to increase income levels and correct market failures and imperfections.

\section{B. LITERATURE REVIEW}

Existing literature on financial inclusion has varying definitions of the concept. Many studies define the concept in terms of financial exclusion, which relates to the broader context of social inclusion. For example, Leyshon (1995) highlights the exclusion of some groups and individuals from gaining access to the formal financial system, while Sinclair (2001) focuses on the inability to access necessary financial services in an appropriate form. In contrast, Mialou (2014) and Sarma (2008) directly define financial inclusion. Mialou (2014) stated that financial inclusion is an economic state where individuals and firms are not denied access to basic financial services.

Honohan (2007) tested the significance of his financial access indicator in reducing income equality. His results show that higher financial access significantly reduces income inequality as measured by the Gini coefficient. However, the link between the two variables depends on which specification is used, i.e., when the access variable is included on its own and/or includes financial depth measure, the results are significant, but the same does not hold when per capita income and dummy variables are included.

\section{RESEARCH METHODOLOGY}

The model is built in this study is the simultaneous equation models using panel data of the 31 provinces in Indonesia in 2005-2013. Econometric model used in this research is multiple regression (Multiple Linear Regression Method). With the specification is the number of poor people affected by income inequality and financial inclusion, so formulated as follows:

$Y=\beta 0+\beta 1 X 1+\beta 2 X 2+e$

Where :

$Y=$ Number of poor people

$\mathrm{X} 1=$ Financial inclusion

$\mathrm{X} 2$ = Inequality of income

$\mathrm{e}=$ Error 
$B 0=$ Constants

B1- B2 = The coefficients of each independent variable

The above equation is a model that will be used in research that will explain the independent variable to dependent variable to get parameter estimation then used the technique of OLS (Ordinary Least Square).

\section{RESULTS}

Table 1

\section{Regression Results}

\begin{tabular}{|c|c|c|c|c|c|c|c|c|}
\hline Model & \multicolumn{2}{|c|}{$\begin{array}{l}\text { Unstandardized } \\
\text { Coefficients }\end{array}$} & $\begin{array}{l}\text { Standardized } \\
\text { Coefficients }\end{array}$ & \multirow[t]{2}{*}{$t$} & \multirow[t]{2}{*}{ Sig. } & \multirow[t]{2}{*}{ df } & \multirow[t]{2}{*}{$\mathrm{F}$} & \multirow[t]{2}{*}{ Sig. } \\
\hline & $B$ & Std. Error & Beta & & & & & \\
\hline (Constant1) & 4955,402 & 751,793 & & 6,591 & 001 & 2 & 18,284 & $.003^{b}$ \\
\hline Fin. iclusion & $-9,395$ & 2,112 & $-1,139$ & $-4,448$ & ,004 & 8 & & \\
\hline disparity & ,353 & ,318 & 284 & 1,110 & ,309 & 6 & & \\
\hline
\end{tabular}

The result shows that within the study period, regression coefficient variable of financial inclusion has negative and significant effect with a coefficient equal to $-9,395$ with significance value equal to 0,004 to the poverty level in Indonesia year 2005-2013. This indicates that financial inclusion has an influence and significant to poverty in Indonesia with a negative relationship.

Inequality variable regression coefficient is positive and significant value with the coefficient value of 0.353 with a significance value of 0.309 to the poverty level in Indonesia year 2005-2013. This means if there is an increasing inequality by 1 percent then an increase in the poverty rate of 0.353 percent.

\section{CONCLUSION}

This research found that financial inclusion can affect overall economic growth thereby reducing poverty, but can increase inequality. There is a negative and significant influence of financial inclusion to poverty, and positive and significant impact inequality to poverty in Indonesia. 


\section{REFERENCES}

Anwar, Anaslswanto; Uppun, Paulus; Reviane, Indraswati Tri Abdi. 2017. The Role of Financial Inclusion to Poverty Reduction in Indonesia. IOSR Journal of Business and Management (IOSR-JBM). Volume 18, Issue 6. Ver. III (Jun. 2016), PP 37-39.

Leyshon, T. 1995. Geographies of Financial Exclusion: Financial Abandonment in Britain and the United States. Transactions of the Institute of British Geographers New Series. 20: pp. 312-341.

Honahan, P. 2007. Cross-Country Variation in Household Access to Financial Services. World Bank Paper Conference on "Access to Finance," Washington, DC.

Park, Cyn-Young and Mercado Jr, Rogelio V. 2016. Financial Incluslon, Poverty, and Income Inequality In Developing Asia. ADB economics working paper series, No. 426 January 2015

Sarel, M. 1997. How Macroeconomic Factors Affect Income Distribution: The Cross-Country Evidence. International Monetary Fund Working Paper No. 97/152. Washington, DC.

Sarma, M. 2008. Index of Financial Inclusion. Indian Council for Research on International Economic Relations Working Paper No. 215.

Sinclair S. P. 2001. Financial exclusion: An Introductory Survey. Report of Centre for Research in Socially Inclusive Services. Heriot-Watt University, Edinburgh.

World Bank. 2016. Global Financial Development Report 2016: Financial Inclusion. Washington, DC. 